\begin{tabular}{|c|c|c|}
\hline 山本 & 裕 & 一色聡一郎 \\
\hline 島田 & 敦 & \\
\hline
\end{tabular}

目的：気腹による静脈䙪滞は，血栓性疾患発症の原 因になりうる，気腹下腹腔鏡的手術の凝固線溶系に及 沽す影響について知るために，10例の腹腔鏡的胆囊摘 出術に扔いて, 主として凝固線溶系の分子マーカーを 測定し，その変動を検討した。

対象と方法：32歳から60歳の, 女性 7 名, 男性 3 名 で, 全例全身麻酔開始後, 両下肢に弾性包帯を巻き, $\mathrm{CO}_{2}$ 気腹圧は $12 \mathrm{mmHg}$ に設定した。採血は麻酔前, 麻 酔導入後 15 分, 気腹開始後 30 分, 気腹解除後 30 分 (弾 性包帯解除後15分)，術後第 $1 ， 3 ， 5 ， 7$ 日目とした。 測定項目は thrombin antithrombin III complex (以 下, TAT), plasmin $\alpha_{2}$ plasmin inhibitor complex (以下, PIC), Fibrinopeptide A (以下, FPA), Fibrinopeptide $\mathrm{B} \beta_{15-42}$ (以下, FPB $\beta_{15-42}$ ) Fibrin degradation products (以下, FDP) Ddimer, Plasminogen (以下, PLG), $\alpha_{2}$ PI とした.

結果：Thrombin 生成マーカーである TAT, FPA は, 気腹解除後 30 分の測定值でピークを示し, TAT は $22.09 \pm 6.02 \mathrm{ng} / \mathrm{ml}$, (mean $\pm \mathrm{SE}$, 以下同じ) FPA は $24.18 \pm 7.14 \mathrm{ng} / \mathrm{ml}$ で, 術前值 (TAT : $1.91 \pm 0.08$, FPA : $3.08 \pm 0.65)$ に比べ有意に増加した $(p<0.05)$. FPA, TATともに術後 1 日目に著減した後, 経日的に 漸減した. Plasmin 生成マーカーであるPIC と, Fibrin 崩壊マーカーの FPB $\beta_{15-42}$ は, 気腹解除後に増加 したが軽度であり，そのピークは術後 $3 ， 5$ 日目にみ られた. FDPDdimerも同椂の変動を示し, 術後の 2 次 線溶の元進を反映した. PLG， $\alpha_{2}$ PI は術中, 術後早期 に減少したが，いずれも正常範囲内の変動であった.

考察：静脈血栓怯古典型なVirchow の 3 因子,すな

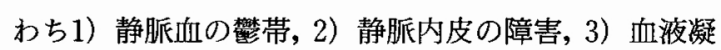
固能の元進，の 3 因子が単独にあるいは相互に密に関 連し, 形成される. 気腹による腹腔内圧上昇は下大静 脈を圧迫し，胆摘術では骨盤低位をとることが多く， 下肢静脈血の鬱帯は増強する1). また, 静脈弁の cup 付
Fig. 1 Time course of the changes in coagulationfibrinolysis during laparoscopic cholecystectomy with pneumoperitoneum.
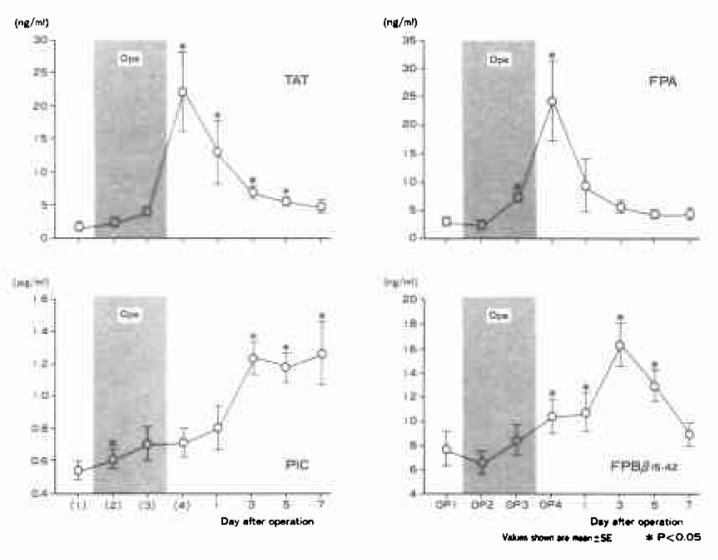

近の血流带が局所的低酸素血症をじゃつ起して静脈 内皮を障害する可能性や, 静脈壁の物理的な過伸展が 静脈内皮を傷害する機序 ${ }^{2}$ が示唆されている.今回の 検討では, 従来の開腹による胆摘術に比べ ${ }^{3)}$, 気腹解除 後のThrombin 産生指標の増加が特に著しく, Plas$\min$ 産生指標の六進を, 大きく凌駕しており, 凝固線 溶活性の不均衡は術後早期に著明だった。手術侵襲に 上る生理的凝固活性の充進 ${ }^{31}$ に加え, 気腹に起因する

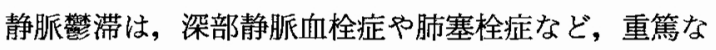
血栓性疾患発症の原因になりうると考える。

Key word : coagulation fibrinilysis on pneumoperitoneum

文献：1) Beebe DS, Mcnevin MP, Crain JM et al: Evidence of venous stasis after abdominal insufflation for laparoscopic cholecystectomy. Surg Gynecol Obstet 176 : 443-447, 1993 2) Karino T, Motomiya M : Flow through a venous valve and its implication for thrombus formation. Thromb Res 36：245-257, 1984 3) 武田成彰, 岡本好司, 加 藤秀典ほか：手術侵襲に基づく凝固・線溶系の反応梯 式. 日外会誌 9:1191-1195, 1990

\title{
The Effect of Pneumoperitoneum on Coagulation Fibrinolysis during Laparoscopic Surgery
}

Yutaka Yamamoto, Hiroyuki Yoshida, Souichirou Issiki, Atsushi Shimada and Masaaki Ueda Department of Surgery, Keio University, Ise Keio Hospital $<1995$ 年11月15日受理 $>$ 別刷請求先: 山本 裕 $\quad$ 个516 伊勢市常盤 $2-7-28$ 